\title{
Recent Advances in the Colorimetric Detection of Cyanide
}

\author{
Felix H. Zelder* and Christine Männel-Croisé
}

\begin{abstract}
This short-review discusses the recent developments in the colorimetric detection of cyanide with different types of receptors. Significant progress in terms of selectivity, sensitivity and straightforwardness has been observed for either organic-, main group- or transition metal-based sensors. Our group has developed a simple and highly specific system for the optical sensing of cyanide based on the conformational switch of commercially available vitamin $B_{12}$.
\end{abstract}

Keywords: Anion sensor - Cyanide · Naked-eye detection · Vitamin $\mathrm{B}_{12}$

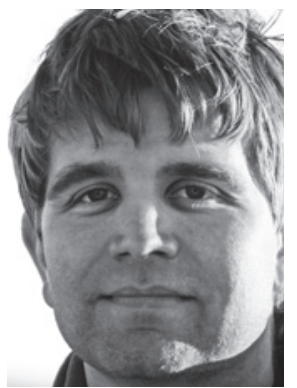

Felix H. Zelder was born on September, 1974 in Marburg, Germany. He studied chemistry at Heidelberg, Germany and Padua, Italy. In 2003, he received his doctoral degree from the university of Heidelberg/Prof. R. Krämer and moved then to the Scripps Research Institute working under the tutelage of Prof. J. Rebek Jr. Since March 2006, Felix Zelder has been working as Oberassistent and Habilitand at the Institute of Inorganic Chemistry of the University of Zürich under the guidance of Prof. R. Alberto. Research in the Zelder group is focused on the development of semi-artificial systems for applications in medicinal chemistry, catalysis and diagnosis. Felix Zelder has been awarded several fellowships and received the Procter and Gamble Award as well as the Sophie Bernthsen Award of the University of Heidelberg.
${ }^{{ }^{*} \text { Correspondence: }}$ Dr. F. H. Zelder Insititute of Inorganic Chemistry University of Zürich Winterthurerstr. 190 $\mathrm{CH}-8057$ Zürich

Tel.: + 41446354624

Fax: + 41446356802

E-mail: zelder@aci.uzh.ch

\section{Introduction}

The cyanide ion is extremely harmful for humans and almost all other forms of life. A concentration between 0.5 and 3.5 $\mathrm{mg}$ per $\mathrm{kg}$ of body weight is lethal to humans depending strongly on the form of exposure, absorption and distribution. ${ }^{[1,2]}$ The toxicity originates from the binding to cytochrome oxidase that inhibits the mitochondrial electron-transport chain. ${ }^{[3]}$ Nevertheless, cyanide is produced in large quantities for different industrial applications like the production of organic chemicals and polymers, the gold extraction process or electroplating. ${ }^{[4]}$ Accidental cyanide release presents great danger for the environment. The disastrous spill of millions of litres of cyanide waste in Romania in 2000 is considered as the worst case of water pollution in Europe ever.[5] On the other hand, cyanide is widespread in nature, e.g. in the form of cyanogenic glycosides in plants like almonds, flax seed, bamboo shoots and cassava. ${ }^{[6]}$ The latter food is one of the most important carbohydrate sources for about 500 million people in the tropical belt. ${ }^{[7]}$ In its raw form it cannot be consumed since cyanide concentrations can reach levels of up to several hundreds of milligrams per kilogram. ${ }^{[1]}$

Therefore it is necessary to safely monitor and remove this dangerous anion either in industrial wastewater, after accidental release or during food production. Since the first report on the argentometric determination of cyanide by von Liebig in $1851,{ }^{[8]}$ many different detection methods including electrometric, ${ }^{[9-11]}$ fluorometric ${ }^{[12,13]}$ and chromatographic techniques ${ }^{[14]}$ have been established. Drawbacks are either the laborious multistep sample pretreatment, the use of special reaction conditions as well as the low tolerance towards the presence of other anions. In addition, most of these methods are time consuming and need expensive and bulky laboratory systems. Therefore, a cheap sensor available to anyone, especially also in the developing countries would be highly desirable. Such a system should detect cyanide below the maximum permissible level in drinking-water of $1.7 \mu \mathrm{M}$ set by the World Health Organisation. ${ }^{[1]}$ Moreover, the detection system should be easy to handle and the results readily understood in form of an absolute yes-no selectivity.

Recently, the development of chemosensors for the selective recognition of anions has attracted much attention. ${ }^{[15-20]}$ Ideally, these systems show a colour change in the presence of the target molecule which is easily detectable with the 'nakedeye'. [21-24] For cyanide sensing, their mode of action is based on hydrogen bonding, ${ }^{[25,26]}$ bond-forming reactions between either the nucleophilic cyanide and an electrophilic carbon ${ }^{[27-36]}$ or boron centre $^{[12,37-39]}$ or metal coordination ${ }^{[40-43]}$ (Scheme 1). Progress is observed for all of these different systems, but a sensor that meets all of following three criteria has not yet been synthesized:

i) optical detection below the maximum permissible level of cyanide in drinking water $(1.7 \mu \mathrm{M})$;

ii) demonstrating a fast and unambiguous response in pure water $(<5 \mathrm{sec})$ without the need for special reaction conditions or sample pre-treatment;

iii) displaying high selectivity in the presence of other anions.

This short-review focuses on the recent advances in the colorimetric detection of cyanide. Approaches like the application of CdS quantum dots ${ }^{[4,45]}$ or luminescence lifetime measurements ${ }^{[13,26,46]}$ will not be discussed here. The interested reader is referred to a comprehensive overview including other detection methods and historical developments by Singh et al. published in 1986. ${ }^{[47]}$ 


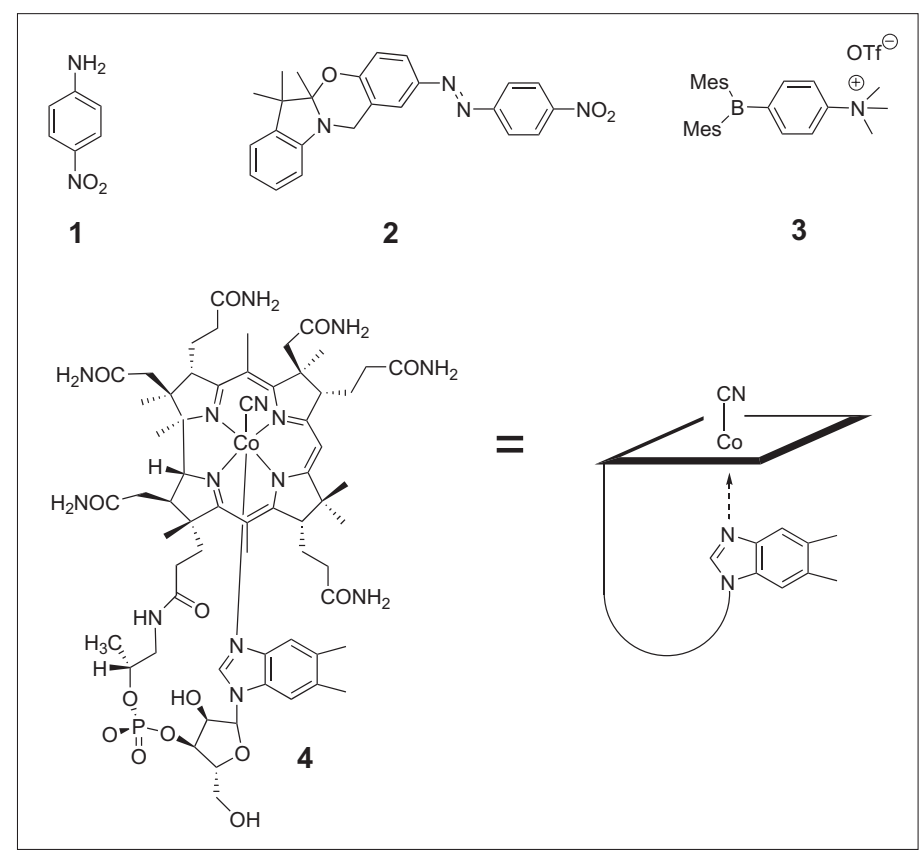

Scheme 1. Examples of different types of receptors for cyanide detection: hydrogen bond donor-based sensor (1), ${ }^{[25]}$ organic-based sensor (2), ${ }^{[2]]}$ boron-based sensor (3) ${ }^{[38]}$ and metal-based sensor (4). ${ }^{[40]}$

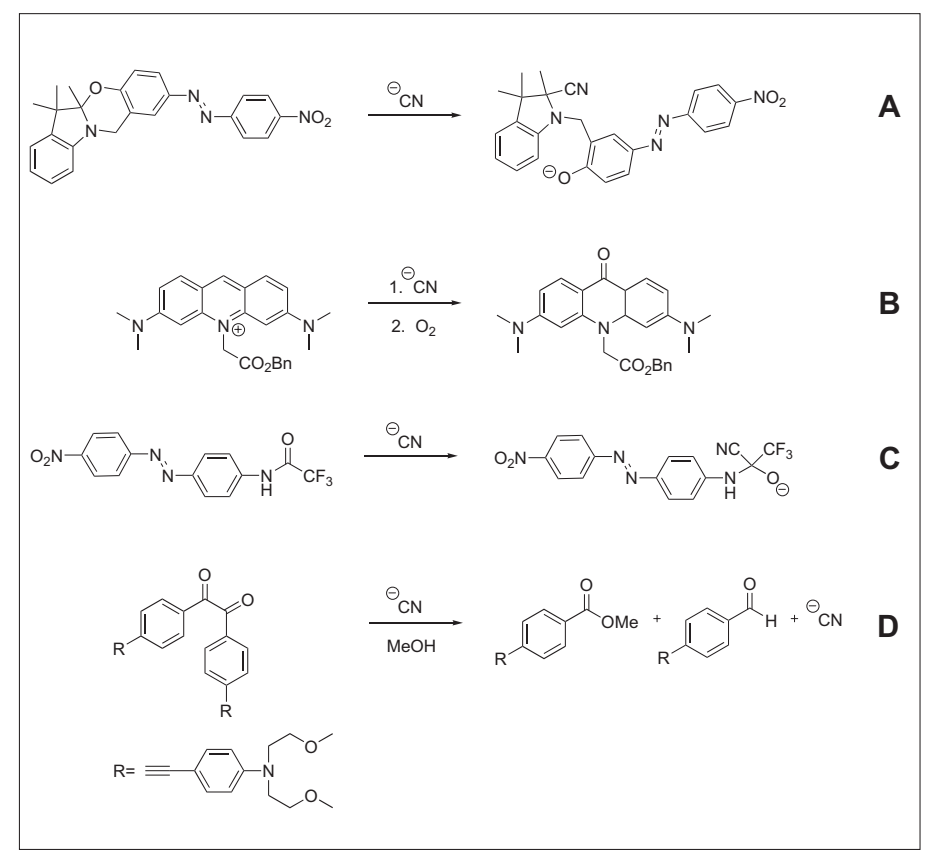

Scheme 2. Cyanide mediated reactions with organic-based sensors $\left(\mathbf{A},{ }^{[28]} \mathbf{B},{ }^{[29]} \mathbf{C},{ }^{[33]} \mathbf{D}^{[27]}\right)$.

\section{Sensors Based on Hydrogen Bonding}

One important class of receptors for the selective recognition and sensing of anions is based on hydrogen bonding interactions between the receptor and the target molecule. ${ }^{[20]}$ These receptors are designed to differentiate between the characteristic hydrogen bond donor-acceptor geometries of their guests. Although very elegant in their design, these receptors are often restricted to organic solvents since only small amounts of water can effectively compete for the binding side.

The recognition of cyanide using hydrogen bonds is rare and only a few examples of receptors have been reported in the literature. ${ }^{[25,26]}$ It has been demonstrated that certain aromatic chromophores with at least one hydrogen bonding donor moiety show a bathochromic shift in the presence of a 100 -fold excess of cyanide $(10 \mathrm{mM})$. The sensors are simple aniline derivatives like 1 (Scheme 1) or commercial available indicators, dyes or stains. In the 'off-the-shelf' approach, ${ }^{[25]}$ the observed colour change is addressed to the formation of a charge-transfer complex between the anion and the receptor molecule. Unfortunately, these 'prototypes' are rather unselective and the specific detection of a target anion following this approach has still to be demonstrated.

\section{Organic-based Sensors}

Picric acid[48,49] and the König synthesis ${ }^{[5,51]}$ have been widely used for the spectrophotometric determination of cyanide. The former reagent is still the method of choice for the detection of cyanide in cassava $^{[52,53]}$ or the ferment of cyanogenic bacteria, ${ }^{[54]}$ but the toxicity and explosiveness of the reagent as well as the slow colorimetric response would make a substitution highly desirable.

Reaction-based sensors take advantage of a colour change after the reaction of nucleophilic cyanide with an electrophilic functional group of an organic chromophore.

In 2005, Raymo et al. applied the cyanide-induced ring opening of a chromogenic $[1,3]$ oxazine to 4-nitrophenylazophenolate for cyanide detection (Scheme 2A). ${ }^{[28]}$ A colour change from yellow to violet $\left(\lambda_{\text {max }}\right.$ $=381 \mathrm{~nm}$ to $\lambda_{\max }=581 \mathrm{~nm}$ ) was observed after the addition of $10 \mathrm{mM}$ cyanide in an acetonitrile-water mixture with no interference of common halides like $\mathrm{F}^{-}, \mathrm{Cl}^{-}$, $\mathrm{Br}^{-}$or $\mathrm{I}^{-}$. It has been demonstrated that the $\mathrm{UV}$-vis detection of $\mu \mathrm{M}$ cyanide is possible under special biphasic conditions, whereas the sensitivity of this sensor is strongly $\mathrm{pH}$ dependant due to the protonation of the phenolate chromophore.

The addition of cyanide to the 9-position of an acridinium salt followed by oxidation with $\mathrm{O}_{2}$ to an acridone induces a large decrease in fluorescence intensity and a colour change from yellow to pale blue (Scheme 2B). [29] Fluorescence and colorimetric monitoring of micromolar cyanide in the presence of fourteen different anions has been observed in DMSOwater, but elevated temperature $\left(50{ }^{\circ} \mathrm{C}\right.$ for $10 \mathrm{~min}$ ) is required and the sensitivity is significantly reduced in the presence of water.

Other nucleophilic addition reactions have been explored including the reaction of cyanide to pyrylium, ${ }^{[30]}$ squarane ${ }^{[31]}$ and either trifluoroacetophenone ${ }^{[32]}$ or trifluoroacetamide derivatives. ${ }^{[33,34]}$ The latter ones are readily prepared from commercial available starting materials and allow the optical detection of $\mu \mathrm{M}$ cyanide in acetonitrile-water mixtures. Varying amounts of water $(0-10 \%)$ have a strong influence on the sensitivity and selectivity of a trifluoracetamide modified organic chromophore (Scheme 2C). This has been explained by the strength of hydration that alters the nucleophilicity of the different anions in an aqueous environment. [33]

Sessler et al. explored the benzil-rearrangement and the benzil-cyanide reaction for cyanide detection. ${ }^{[27,36,55]}$ Both reactions proceed via the same intermediate to either a rearranged product in aprotic solvents or after cleavage in protic solvents to the corresponding benzaldehyde and benzoate ester. Especially the latter reaction, the socalled benzil-cyanide reaction seems to be very attractive since only catalytic amounts of cyanide are potentially required to trigger the reaction (Scheme 2D).

During both types of reactions a change in the conjugated $\pi$-system results in a visible colour change.

In aprotic solvents, a blue shift $\left(\Delta \lambda_{\text {max }}\right.$ $=56 \mathrm{~nm}$ ) from yellow to colourless was observed after one minute and the addition of 3 equiv. of cyanide to the sensor $(2.13$ $\left.\times 10^{-5} \mathrm{M}\right)$. Since the product of the benzil- 
rearrangement is fluorescent, the limit of detection with an ordinary laboratory UV lamp is as low as $20 \mu \mathrm{M}$ in organic solutions. [36]

The benzil reaction leads to a remarkable enhanced cyanide sensitivity (Scheme 2D). ${ }^{[27]}$ The reaction occurs in methanolwater mixtures, but the addition of base $(\mathrm{NaOH}, 5 \mathrm{mM})$ is necessary for the reaction to be completed within a reasonable time. A blue shift in the absorption spectra maximum $\left(\Delta \lambda_{\max }=43 \mathrm{~nm}\right)$ is observed after $\mathrm{C}-\mathrm{C}$ bond breakage and is reflected in a colour change from yellow to colourless. A limit of detection of less than $1.7 \mu \mathrm{M}$ can be obtained with simple 'naked-eye' detection with no interference of various competing anions. Drawbacks of this system are still the need of organic co-solvents, the addition of base and the relatively long reaction time between 10 and $60 \mathrm{~min}$.

\section{Sensors Based on Boron Coordination}

Electron-deficient Lewis acids can saturate their electronic demand through anion coordination. This has led to the development of a variety of different chelating receptors and sensors based on threecoordinated boron species. ${ }^{[20]}$ Boronic acid derivatives have been successfully applied in the fluorometric sensing of micromolar aqueous cyanide, ${ }^{[12]}$ whereas fluorescent triarylborane polymers probe micromolar cyanide in organic solvents. ${ }^{[37]}$ Recently, Gabbai et al. applied two isomeric cationic ammonium boron derivatives for the selective recognition of either cyanide or fluoride ions in water (Scheme 3E). ${ }^{[38]} \mathrm{Al}-$ though both receptors show no selectivity in organic solvents, selective binding of either cyanide or fluoride to the corresponding para-cyanoborate or ortho-fluoroborate ammonium zwitterions has been observed in aqueous solutions. Computational studies underscore the importance of electronic and steric effects of the ammonium groups for the observed selectivity in water. Fluorescence detection of $5 \mu \mathrm{M}$ cyanide with an ordinary laboratory UV lamp has been communicated in water-methanol 90:10 (v/v).

A two-component system composed of ferrocene-functionalised borane derivatives and an redox-active dye can be applied for the detection of cyanide and fluoride in organic solvents (Scheme 3F). ${ }^{39]}$ The anion binding to the Lewis acidic borane centre induces a cathodic shift of the ferrocene moiety between -300 and -600 $\mathrm{mV}$ that reduces a tetrazolium redoxactive dye. Depending on the system, the visual detection of 25-40 nmol cyanide has been reported. Moreover, fine-tuning of the receptor-dye system can be easily obtained by the combination of an appro-

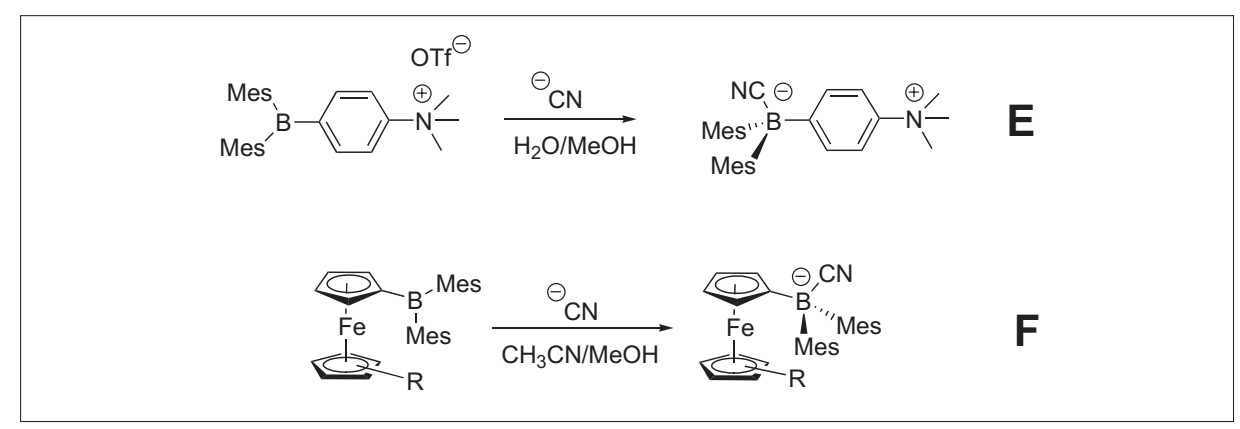

Scheme 3. Cyanide detection with boron-based sensors $\left(\mathbf{E},{ }^{[38]} \mathbf{F}^{[39]}\right)$.

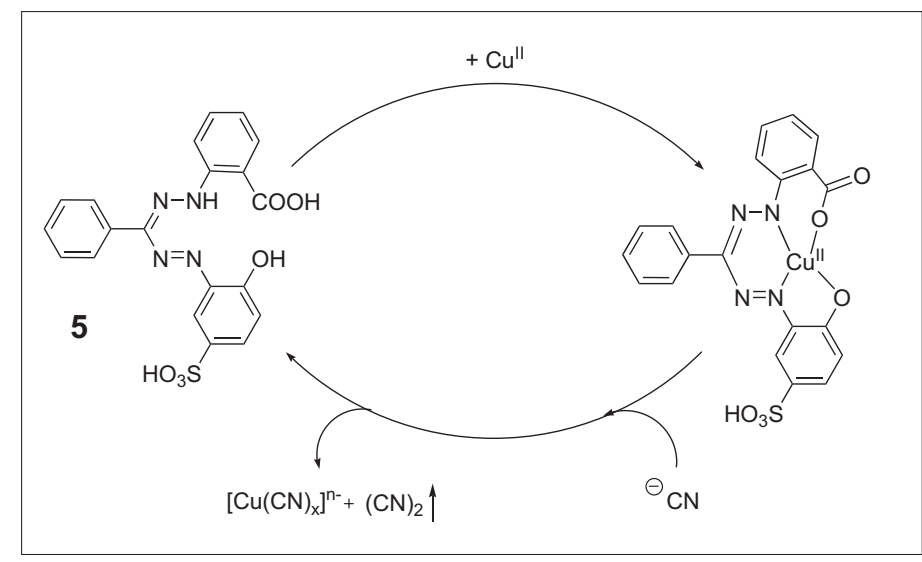

Scheme 4. Proposed mechanism for the conversion of zincon (5) with $\mathrm{Cu}(\mathrm{II})$ and cyanide. ${ }^{[43]}$

priate ferrocene-modified Lewis acid and a suitable redox-active dye. Following this strategy, the selective recognition of fluoride over cyanide with a weak Lewis acidic stilbene diolate boronic ester receptor has been achieved. The authors explain the observed selectivity with the relatively high B-F bond strength. ${ }^{[39]}$

\section{Sensors Based on Transition- metal Coordination}

Transition metal cyanide chemistry dates back to 1704 when the artist Diesenbach discovered accidentally Prussian Blue. The high affinity of cyanide to transition metals has led to numerous metal complexes with different bonding and structural motifs and a broad spectrum of different applications.[56] The formation of coloured water-insoluble cyano-metal complexes has already led to the development of a variety of different spot tests, ${ }^{[47]}$ that can detect as low as $8 \mu \mathrm{M}$ cyanide. ${ }^{[57]}$ Drawbacks are the interference with various different anions as well as the timeconsuming sample preparation and/or slow colorimetric response. A short time ago, different research groups have applied novel transition metal-based receptors to overcome these limitations. [11]

A Zn-porphyrin-crown ether conjugate facilitates the ditopic recognition of $\mathrm{NaCN}$ in aprotic organic solvents accompanied by a colour change from red to green. Although selective in organic solvents, the sensor shows a low sensitivity for the de- tection of hydrated cyanide under biphasic conditions. ${ }^{[42]}$

A cyanide-bridged heterobimetallic $\mathrm{Ru}(\mathrm{II})-\mathrm{Cu}(\mathrm{II})$ donor-acceptor complex is cleaved after the addition of cyanide, which results in a blue shift $\left(\Delta \lambda_{\max }=16\right.$ $\mathrm{nm})$ and a colour change from green to orange. A significant enhancement of luminescence of the liberated $\mathrm{Ru}$ (II)-cyano complex is observed with a detection limit of $1.2 \mu \mathrm{M}$ in aqueous DMF. The specificity towards cyanide can be explained by the higher thermodynamic stability of the $\mathrm{Cu}$ (II) complex to cyanide than to the $\mathrm{Ru}$ (II) donor moiety of the sensor assembly. ${ }^{[41]}$

In 2008, the decomplexation of a $\mathrm{Cu}(\mathrm{II})$ zincon (2-carboxy-2'-hydroxy-5' sulfoformazylbenzene) complex was applied for cyanide sensing (Scheme 4). ${ }^{[43]}$ The demetalation of the complex can be followed by a blue shift of the absorption $\operatorname{maximum}\left(\Delta \lambda_{\max }=137 \mathrm{~nm}\right)$ and a colour change from blue to yellow. Following this approach, as low as $20 \mu \mathrm{M}$ cyanide can be detected with the 'naked-eye' in pure water. Only $\mu \mathrm{M}$ fluoride interferes, probably due to the coordination to a pentacoordinated $\mathrm{Cu}$ (II) complex. It must be noted here that the reaction between redox-active $\mathrm{Cu}$ (II) and cyanide could lead to the formation of highly toxic dicyan gas. ${ }^{58]}$ Therefore, another suitable redox-inactive metal ion should be chosen as an alternative.

The absorption spectra of metalloporphyrins and corrinoids is strongly dependant on the nature of additional axial ligands, ${ }^{[59,60]}$ and this has led to the development of different detection methods for 

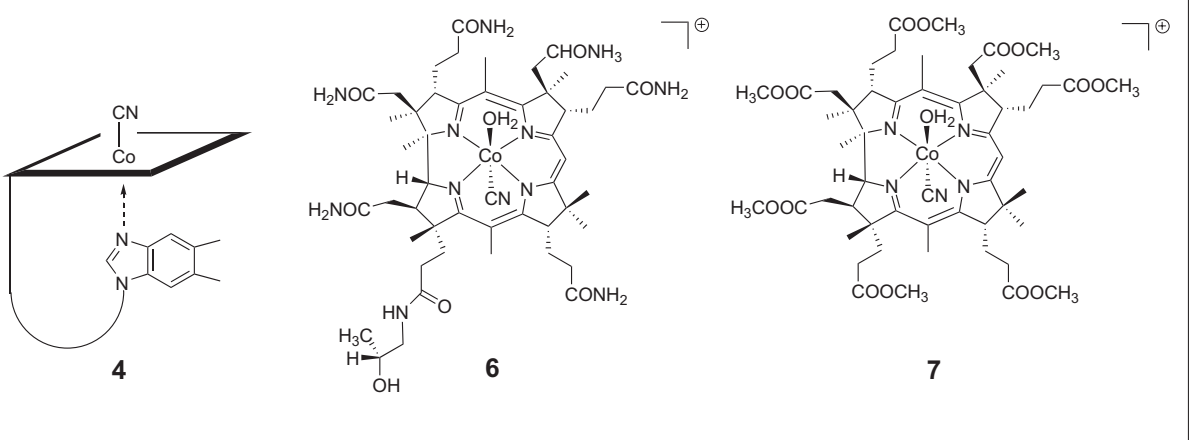

Scheme 5. Different Co(III)-corrinoids applied for the detection of cyanide $\left(\mathbf{4},{ }^{[40]} \mathbf{6},,^{[62]} \boldsymbol{7}^{[64]}\right)$.

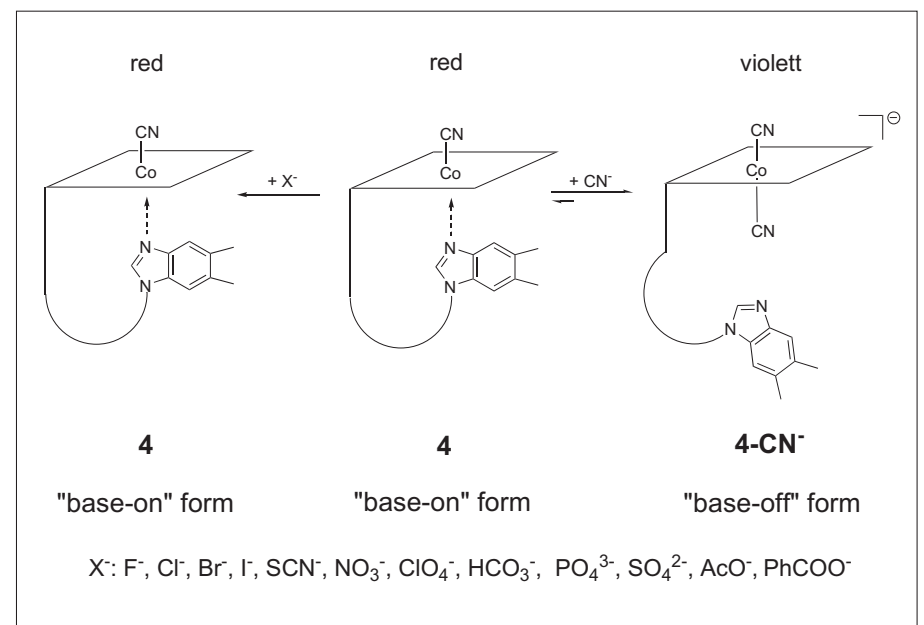

Scheme 6. Mechanism of the vitamin $\mathrm{B}_{12}$ based sensor. ${ }^{[40]}$

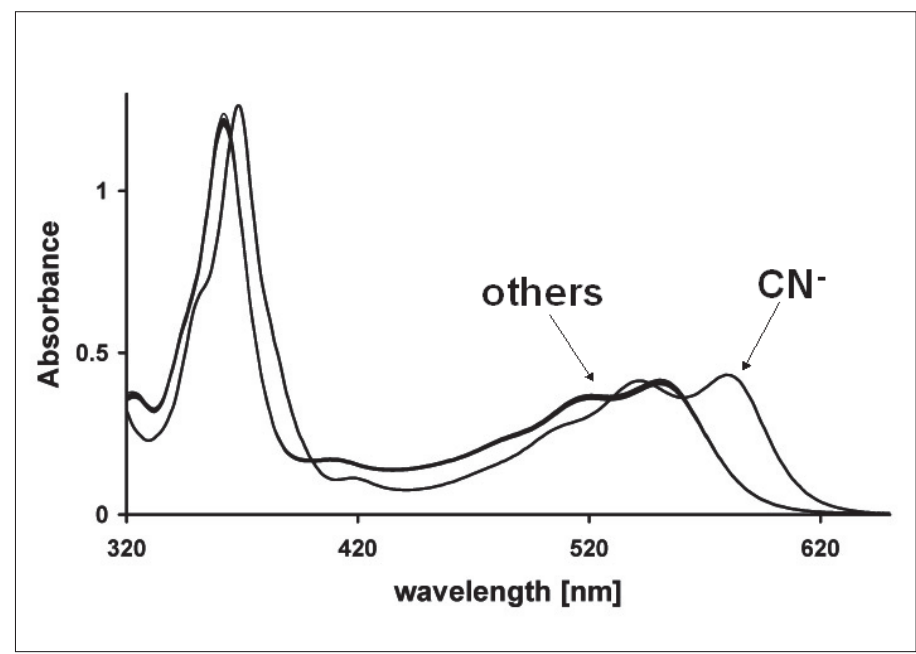

Fig. 1. Absorption spectra of solutions of $\mathrm{B}_{12}(50 \mu \mathrm{M})$ treated with $\mathrm{F}^{-}, \mathrm{Cl}^{-}, \mathrm{Br}, \mathrm{I}^{-}$, $\mathrm{SCN}^{-}, \mathrm{CN}^{-}, \mathrm{NO}_{3}^{-}, \mathrm{ClO}_{4}^{-}$, $\mathrm{HCO}_{3}^{-}, \mathrm{PO}_{4}^{-}, \mathrm{SO}_{4}^{2-}$, $\mathrm{AcO}^{-}, \mathrm{PhCOO}^{-}(5 \mathrm{mM})$ in water ([Hepes] $=20$ $\mathrm{mM} ; \mathrm{pH} 7.6 \pm 0.1)$ at $\mathrm{T}$ $=22 \pm 2{ }^{\circ} \mathrm{C}$. Reprinted with permission from ref. [40]. Copyright 2008 American Chemical Society. cyanide. ${ }^{[40,61-64]}$ Bachas et al. incorporated aquocyanocobinamide $\mathbf{6}$ into fibre-optic chemical sensors (FOCS) and detected after generation of $\mathrm{HCN}$ under acidic conditions and diffusion through a membrane as low as $10 \mu \mathrm{M}$ cyanide within $2 \mathrm{~min}$ and no interference of different anions (Scheme 5). ${ }^{\left[{ }^{62]}\right.}$ Aquocyano-cobester 7 (Scheme 5) ${ }^{[64]}$ and solid-support bound aquocyano-Co(III) corrinoids $^{[65]}$ are highly sensitive and selective probes for the spectrophotometric detection of cyanide. A detection limit of $0.8 \mu \mathrm{M}$ cyanide in water at $\mathrm{pH} 9.5$ has been reported with compound 7.[64] We assume that a mixture of different isomers was applied in these experiments, since we observed in our studies the hydrolysis of the methylester functionalities of $\mathbf{7}$ under the reported conditions. [66]

We communicated recently the optical detection of millimolar cyanide in water at pH 7.5 with commercial available vitamin $\mathrm{B}_{12} \cdot{ }^{[40]}$ The mode of operation is controlled by the natural benzimidazole trigger of being able to switch between different conformations (Scheme 6). ${ }^{67]}$ A switch from the 'base on' form to the negatively charged 'base off' form of $B_{12}$ is observed after cyanide coordination that results in a bathochromic shift $\left(\Delta \lambda_{\text {max }}=30 \mathrm{~nm}\right)$ and can be followed by a colour change from red to violet. We assume that the high thermodynamic stability of Co(III)-cyano complexes is the driving force for the substitution of the intramolecularly bound dimethylbenzimidazole base. Other anions are not nucleophilic enough to replace the strongly coordinated base $\left(\mathrm{pk}_{\mathrm{a}}\left(\mathrm{H}\right.\right.$-vitamin $\left.\mathrm{B} 12^{+}\right)=$ 0.1 ; with protonation at the dimethylbenzimidazole nitrogen N(3)) in water (Fig. 1, 2). ${ }^{[68]}$ In various competition experiments it was demonstrated that up to twelve different anions as well as a 1000-fold excess of $\mathrm{Cl}^{-}$over $\mathrm{CN}^{-}$do not interfere with the sensor. Unfortunately, only millimolar concentrations of cyanide can be detected at neutral $\mathrm{pH}$ and the reaction time of 10 min at room temperature has to be improved. Momentarily, we are attempting to develop modified corrinoids that overcome these limitations in the near future.

\section{Summary and Perspectives}

Since the first report in 1851 , the development of receptors and sensors for the detection of cyanide is an active ongoing research area in organic, main group and transition metal chemistry. In the last decade, impressive progress has been observed for the development of novel sensors displaying a simple yes-no selectivity in form of a colorimetric response. In any of the different approaches either the selectivity, sensitivity or the tolerance towards water has been significantly improved. Never-
Fig. 2. Colour of solutions of $\mathrm{B}_{12}(50 \mu \mathrm{M})$ treated with $\mathrm{F}^{-}, \mathrm{Cl}^{-}, \mathrm{Br}^{-}, \mathrm{I}^{-}, \mathrm{SCN}^{-}, \mathrm{CN}^{-}, \mathrm{NO}_{3}^{-}, \mathrm{ClO}_{4}^{-}, \mathrm{HCO}_{3}^{-}$, $\mathrm{PO}_{4}^{3-}, \mathrm{SO}_{4}^{2-}, \mathrm{AcO}^{-}, \mathrm{PhCOO}^{-}\left(5 \mathrm{mM}\right.$; from left to right) in water ([Hepes] $=20 \mathrm{mM}$; $\left.\mathrm{pH}^{3} 7.6 \pm 0.1\right)$ at $\mathrm{T}$ $=22 \pm 2{ }^{\circ} \mathrm{C}$. Reprinted with permission from ref. [40]. Copyright 2008 American Chemical Society. 
theless, none of these systems seems to be perfect yet and do not meet the three criteria of sensitivity, selectivity and straightforwardness discussed in the introduction. Far more work is certainly needed for the development of a simple, fast, cheap and reliable detection system.

\section{Acknowledgement}

Our group is financially supported by the Forschungskredit of the University of Zurich and the Swiss National Science Foundation (SNSF). The authors are grateful to Bernhard Spingler and Roger Alberto for helpful discussions and to R.A. for generous support.

Received: January 12, 2009

[1] 'Background Document for Development of WHO Guidelines for Drinking-water Quality', World Health Organization, Geneva, Switzerland, 2007.

[2] S. I. Baskin, T. G. Brewer, in 'Medical Aspects of Chemical and Biological Warfare', Eds. F. Sidell, E. T. Takafuji, D. R. Franz, TMM Publications, Washington DC, 1997, p. 271.

[3] L. P. Solomonson, in 'Cyanide in Biology', Eds. B. Vennesland, E. E. Conn, C. J. Knowles, J. Westley, F. Wissing, Academic Press, London, 1981, p. 11.

[4] C. Young, L. Tidwell, C. Anderson, in 'Cyanide: Social, Industrial, and Economic Aspects', Ed. Minerals, Metals, and Material Society, Warrendale, 2001.

[5] R. Koenig, Science 2000, 287, 1737.

[6] R. D. Cooke, D. G. Coursey, in 'Cyanide in Biology', Eds. B. Vennesland, E. E. Conn, C. J. Knowles, J. Westley, F. Wissing, Academic Press, London, 1981, p. 93.

[7] G. Padmaja, Crit. Rev. Food Sci. 1995, 35, 299.

[8] J. v. Liebig, Annalen 1851, 77, 102.

[9] J. Fligier, P. Czichon, Z. Gregorowicz, Anal. Chim. Acta 1980, 118, 145 .

[10] B. Vallejo-Pecharroman, M. D. L. de Castro, Analyst 2002, 127, 267.

[11] B. Ahlers, K. Cammann, S. Warzeska, R. Kramer, Angew. Chem., Int. Ed. Engl. 1996, 35, 2141.

[12] R. Badugu, J. R. Lakowicz, C. D. Geddes, J. Am. Chem. Soc. 2005, 127, 3635.

[13] P. Anzenbacher, D. S. Tyson, K. Jursikova, F. N. Castellano, J. Am. Chem. Soc. 2002, 124, 6232 .

[14] M. Aguilar, A. Farran, V. Marti, J. Chromatogr. A $1997,778,397$.

[15] R. Martinez-Manez, F. Sancenon, Chem. Rev. 2003, 103, 4419

[16] T. S. Snowden, E. V. Anslyn, Curr. Opin. Chem. Biol. 1999, 3, 740 .

[17] F. P. Schmidtchen, M. Berger, Chem. Rev. 1997, 97, 1609.
[18] D. M. Rudkevich, Z. Brzozka, M. Palys, H. C. Visser, W. Verboom, D. N. Reinhoudt, Angew. Chem. Int. Ed. Engl. 1994, 33, 467.

[19] A. P. deSilva, H. Q. N. Gunaratne, T. Gunnlaugsson, A. J. M. Huxley, C. P. McCoy, J. T. Rademacher, T. E. Rice, Chem. Rev. 1997, 97, 1515 .

[20] P. D. Beer, P. A. Gale, Angew. Chem., Int. Ed. 2001, 40, 486

[21] A. Metzger, E. V. Anslyn, Angew. Chem., Int. Ed. 1998, 37, 649 .

[22] A. Buryak, K. Severin, J. Am. Chem. Soc. 2005 , 127,3700

[23] K. N. Koh, K. Araki, A. Ikeda, H. Otsuka, S Shinkai, J. Am. Chem. Soc. 1996, 118, 755.

[24] P. A. Gale, L. J. Twyman, C. I. Handlin, J. L. Sessler, Chem. Commun. 1999, 1851.

[25] H. Miyaji, J. L. Sessler, Angew. Chem., Int. Ed. 2001, 40,154

[26] S. S. Sun, A. J. Lees, Chem. Commun. 2000 1687.

[27] D.-G. Cho, J. H. Kim, J. L. Sessler, J. Am Chem. Soc. 2008, 130, 12163.

[28] M. Tomasulo, F. M. Raymo, Org. Lett. 2005, 7 , 4633.

29] Y. K. Yang, J. Tae, Org. Lett. 2006, 8, 5721.

[30] F. Garcia, J. M. Garcia, B. Garcia-Acosta, R. Martinez-Manez, F. Sancenon, J. Soto, Chem. Commun. 2005, 2790.

[31] J. V. Ros-Lis, R. Martinez-Manez, J. Soto, Chem. Commun. 2002, 2248.

[32] Y. M. Chung, B. Raman, D. S. Kim, K. H. Ahn, Chem. Commun. 2006, 186.

[33] H. T. Niu, X. L. Jiang, J. Q. He, J. P. Cheng, Tetrahedron Lett. 2008, 49, 6521.

[34] H. T. Niu, D. D. Su, X. L. Jiang, W. Z. Yang, Z. M. Yin, J. Q. He, J. P. Cheng, Org. Biomol. Chem. 2008, 6, 3038.

[35] S.-J. Hong, J. Yoo, S.-H. Kim, J. S. Kim, J. Yoon, C.-H. Lee, Chem. Commun. 2009, in press.

[36] J. L. Sessler, D. G. Cho, Org. Lett. 2008, 10, 73.

[37] K. Parab, K. Venkatasubbaiah, F. Jakle, J. Am. Chem. Soc. 2006, 128, 12879.

[38] T. W. Hudnall, F. P. Gabbai, J. Am. Chem. Soc 2007, 129, 11978.

[39] A. E. J. Broomsgrove, D. A. Addy, C. Bresner, I. A. Fallis, A. L. Thompson, S. Aldridge, Chem. Eur. J. 2008, 14, 7525.

[40] F. H. Zelder, Inorg. Chem. 2008, 47, 1264.

[41] C. F. Chow, M. H. W. Lam, W. Y. Wong, Inorg. Chem. 2004, 43, 8387

[42] Y. H. Kim, J. I. Hong, Chem. Commun. 2002, 512.

[43] X. Lou, L. Zhang, J. Qin, Z. Li, Chem. Commun. 2008, 5848 .

[44] W. J. Jin, M. T. Fernandez-Arguelles, J. M. Costa-Fernandez, R. Pereiro, A. Sanz-Medel, Chem. Commun. 2005, 883.

45] A. Touceda-Varela, E. I. Stevenson, J. A. GalveGasion, D. T. F. Dryden, J. C. Mareque-Rivas, Chem. Commun. 2008, 1998.
[46] R. Badugu, J. R. Lakowicz, C. D. Geddes, Curr. Anal. Chem. 2005, 1, 157.

[47] H. B. Singh, N. Wasi, M. C. Mehra, Int. J. Environ. Anal. Chem. 1986, 26, 115

[48] R. G. Smith, J. Am. Chem. Soc. 1929, 51, 1171.

[49] F. B. Fisher, J. S. Brown, Anal. Chem. 1952, 24, 1440

[50] W. N. Aldridge, Analyst 1945, 70, 474.

[51] J. L. Royer, J. E. Twichell, S. M. Muir, Anal. Lett. 1973, 6, 619.

[52] M. G. Bradbury, S. V. Egan, J. H. Bradbury, J. Sci. Food Agr. 1999, 79, 593

[53] J. H. Bradbury, Food Chem. 2009, 113, 1329.

[54] H. Brandl, S. Lehmann, M. A. Faramarzi, D. Martinelli, Hydrometallurgy 2008, 94, 14

[55] H. Kwart, M. M. Baevsky, J. Am. Chem. Soc. 1958, $80,580$.

[56] K. R. Dunbar, R. A. Heintz, Prog. Inorg. Chem. 1997, 45, 283.

[57] A. O. Gettler, L. Goldbaum, Anal. Chem. 1947, $19,270$.

[58] A. F. Holleman, E. Wiberg, in 'Lehrbuch der anorganischen Chemie', Ed. A. F. Holleman, E. Wiberg, de Gruyter, Berlin, New York, 1985, p. 1003 .

[59] K. M. Smith, in 'Porphyrins Metalloporphyrins', Ed. K. M. Smith, Elsevier, Amsterdam, 1975, p. 3.

[60] J. M. Pratt, in 'Inorganic Chemistry of Vitamin $\mathrm{B}_{12}$ ', Ed. J. M. Pratt, Academic Press, New York, 1972, p. 44.

[61] K. Poland, E. Topoglidis, J. R. Durrant, E. Palomares, Inorg. Chem. Commun. 2006, 9 , 1239

[62] M. K. Freeman, L. G. Bachas, Anal. Chim. Acta 1990, 241, 119.

[63] S. Daunert, L. G. Bachas, Anal. Chem. 1989 , $61,499$.

[64] S. S. M. Hassan, M. S. A. Hamza, A. E. Kelany, Talanta 2007, 71, 1088.

[65] J. Fuchs, D. Radloff, J. Reichert, H.-J. Ache, Ger. Off. DE 19608808, 1997.

[66] C. Männel-Croise, F. Zelder, unpublished results.

[67] C. L. Drennan, S. Huang, J. T. Drummond, R. G. Matthews, M. L. Ludwig, Science 1994, 266, 1669.

[68] K. L. Brown, Chem. Rev. 2005, 105, 2075. 